\title{
Usefulness of Centor Score to Diagnosis of Group a Streptococcal Pharyngitis and Decision Making of Antibiotics Use
}

\author{
Hye Ran Lee, Jeong Tae Kim, Jae Yong Lee, Jae-Min Shin, \\ Jae Wook Kim, Byung Don Lee, and Kyurin Hwang \\ Department of Otorhinolaryngology-Head and Neck Surgery, Soonchunhyang University College of Medicine, Seoul, Korea
}

\section{$\mathrm{A}$ 군 연쇄구균 인두염의 진단 및 항생제 사용 여부 결정에서 Centor Score의 유용성}

이혜란 · 김정태 · 이재용 · 신재민 · 김재욱 · 이병돈 · 황규린

순천향대학교 의과대학 이비인후과학교실

Received July 4, 2017

Revised August 14, 2017

Accepted August 22, 2017

Address for correspondence

Kyurin Hwang, MD

Department of Otorhinolaryngology-

Head and Neck Surgery,

Soonchunhyang University

College of Medicine,

59 Daesagwan-ro, Yongsan-gu,

Seoul 04401, Korea

Tel $+82-2-709-9360$

Fax $+82-2-709-9134$

E-mail enthkr@gmail.com
Background and Objectives This study aims to verify the usefulness of Centor scores to diagnose the Group A Streptococcal pharyngitis.

Subjects and Method The subjects of this study were 379 patients who had been examined by the rapid antigen detection test (RADT) for Group A Streptococcus. We analyzed their medical records and laboratory test results retrospectively and compared the results of Centor symptom scores with those of RADT. Then we analyzed the association of RADT, the Centor score and the laboratory test results statistically.

Results There were no correlation between the RADT results and fever, cough, tonsillar enlargement, nasal symptoms, myalgia or chilling ( $p>0.05$ ). In the RADT positive group, there were more patients with tonsillar exudate, neck lymph node enlargement, tenderness and pharyngeal abscess formation significantly $(p<0.05)$. The Centor score and C-reactive protein were significantly higher in the RADT positive group $(p<0.05)$.

Conclusion The results of this study suggest that Centor symptom scores can be used to determine which antibiotics to use. The Centor score system can help reduce medical costs and detect the problematic Group A Streptococcal pharyngitis.

Korean J Otorhinolaryngol-Head Neck Surg 2018;61(1):35-41

Key Words Centor score - Pharyngitis - Rapid antigen detection test .

Streptococcus pyogenes.

\section{서 론}

급성 인두염은 인두후벽 및 구개편도 및 주위 림프 조직의 급성 염증성 변화가 나타나는 질환으로, 편도염 및 인두편도 염을 포함하며, 전체 의료기관을 방문하는 환자의 $5 \%$ 정도 를 차지하는 매우 흔한 질환이다.,2) 위산역류 및 술, 담배로

This is an Open Access article distributed under the terms of the Creative Commons Attribution Non-Commercial License (http://creativecommons.org/licenses/by-nc/4.0) which permits unrestricted non-commercial use, distribution, and reproduction in any medium, provided the original work is properly cited.
인한 자극, 알레르기성 비염 등을 포함한 비감염성 원인으로 발생하기도 하나, 대부분은 바이러스 및 세균 감염에 의해 발생하며, 이들 중 $75 \%$ 에서 바이러스가 원인으로 항생제 투 여 없이 호전되는 양성 경과를 보인다. ${ }^{3)}$ 급성 인두염을 일으 킬 수 있는 세균에는 가장 흔한 원인균인 Streptococcus pyogenes (Group A $\beta$-hemolytic Streptococci, A군 베타 용혈 성 연쇄구균) 및 Group C \& G streptococci, Neisseria gonorrhoeae, Corynebacterium diphtheriae, Haemophilus influenzae, Mycoplasma pneumoniae, mixed anaerobes 등 
이 있다. ${ }^{4)}$ 이들 중 $\mathrm{A}$ 군 연쇄구균은 전체 성인 인두염 원인균 의 $5 \sim 15 \%$ 를 차지하며, 급성 화농성 합병증으로 편도 주위 농 양, 균혈증을 일으킬 수 있고, 감염 후기 전신 합병증으로 급 성 류마티스 열, 류마티스 심근염, 연쇄구균 감염 후 사구체 신염을 일으킬 수 있다. 따라서 이러한 합병증의 예방을 위해 $\mathrm{A}$ 군 연쇄구균 인두염을 정확히 진단하고 적절히 항생제를 사용하여 치료하는 것이 임상적으로 중요하다. ${ }^{5)}$

급성 인두염의 임상 증상 및 진찰 소견만으로는 그 원인이 세균인지 바이러스인지 여부 구분이 어려우며, 원인균 확인을 위한 가장 이상적인 검사인 인두배양검사의 경우 결과 확인 까지 18 48시간이 소요되어 실제 임상에서 급성 병색을 보이 는 환자에게 배양검사 결과 확인 후 치료 방향을 결정하기는 현실적으로 어렵다. 이로 인해 경험적 항생제 투여가 빈번하 게 이루어지고 있으며, 이는 내성균 출현과 항생제 남용으로 인한 전체 의료비용 증가를 야기하여 바람직하지 않다.

인두배양검사가 가지는 이러한 제한점을 고려하여 항생제 투여가 반드시 필요한 유일한 원인균인 $\mathrm{A}$ 군 연쇄구균 감염 여 부 판단을 위한 노력으로, 1981년 American College of Physicians-American Society of Internal Medicine 및 미국 질 병통제예방센터(Centers for Disease Control and Prevention) 에서 발표한 Centor score는 현재까지 가장 널리 쓰이고 있는 임상적 예측 가이드라인이다. 15 세 이상 환자들에서 $\mathrm{A}$ 군 연쇄 구균 감염에 의한 인두염 가능성을 판단하기 위한 증상 지 표 4가지: $38^{\circ} \mathrm{C}$ 이상의 발열, 기침 동반하지 않음, 편도 종창 또는 삼출물, 전경부 림프절의 비대 및 압통을 제시하며, 점 수가 높을수록 배양검사에서 실제로 $\mathrm{A}$ 군 연쇄구균이 확인 될 가능성이 높다(Table 1). Centor score는 나이 지표를 추 가하여 어린이들에게도 적용할 수 있는 McIsaac score와 함 께 현재까지 급성 인두염의 치료 방향 결정에 널리 사용되고

Table 1. The Centor score

\begin{tabular}{cc}
\hline \multicolumn{1}{c}{ Criteria } & Points \\
\hline Fever $\left(>38.0^{\circ} \mathrm{C}\right)$ & +1 \\
Absence of cough & +1 \\
Swollen and tender anterior & +1 \\
cervical nodes & +1 \\
\hline Tonsillar swelling or exudates & Post-test probability (\%) \\
\hline Score & 2.5 \\
\hline 0 & 6.5 \\
2 & 15.4 \\
3 & 31.6 \\
4 & 55.7 \\
\hline
\end{tabular}

Patients receive 1 point for the presence or absence of signs and symptoms. Each patient is assigned a score between 0 and 4 which is associated with a post-test probability as calculated by Centor and colleagues
있다. 2,6,7)

또한 최근 개발된 A군 연쇄구균 신속항원검사법(Rapid Group A Streptococcus Antigen Test)은 인후배양검사의 단점을 보완하여 15 분 만에 $\mathrm{A}$ 군 연쇄구균 감염 여부를 확인 할 수 있는 검사이다. 이전부터 여러 연구에서 65 95\%의 민감 도 및 62 97\%의 특이도가 확인되었으며, 최근 시행한 연구 들에서는 일반적으로 $90 \%$ 이상의 민감도 및 특이도를 보이 는 유용한 검사이다. ${ }^{5,8}$ 응급실 또는 1 차 의료기관에서도 저 렴한 비용으로 간단하게 검사하여 $\mathrm{A}$ 군 연쇄구균을 확인할 수 있는 방법이다. 미국 감염학회의 A군 연쇄구균 인두염의 치료 가이드라인에서는 항생제 사용 전 반드시 신속항원검사 를 시행하도록 권고하고 있다." 하지만 국내의 1 차 의료기관의 실정 및 국민이 기대하는 의료비 수준을 감안하였을 때 신속 항원검사의 무조건적인 시행은 여러 가지 어려움이 예상된다.

본 연구에서는 국내 현실을 반영하여 순천향대학교 서울 병원 응급실에 내원한 급성 인두염 환자를 대상으로 환자가 호소하는 증상 및 진찰 소견과 신속항원검사 결과와의 관련 성을 평가하여, 실제 임상에서 $\mathrm{A}$ 군 연쇄구균 감염 여부의 빠 른 판단에 이용할 수 있는 Centor score의 유용성을 신속항 원검사법의 결과와 비교하여 확인하고자 하였다.

\section{대상 및 방법}

2015년 11월 1일부터 2016년 12월 31일까지 순천향대학교 서울병원 응급실을 내원한 환자 중 급성 인후통과 인두발적 또는 편도의 이상을 함께 보여 급성 인두염이 의심되며, $\mathrm{A}$ 군 연쇄구균 신속항원검사를 시행한 환자들을 대상으로 하여 후향적으로 의무기록을 분석하였다. 해당 기간에 응급실에 내원하여 $\mathrm{A}$ 군 연쇄구균 신속항원검사를 시행한 737명 중 폐 렴, 신우신염, 쓸개염 등 다른 장기의 질환이 확인된 환자들, Centor score를 적용할 수 없는 15세 미만의 환자들을 제외 한 총 379 명을 대상으로 하였다. 본 연구는 순천향대학교 임 상시험심사위원회의 승인을 얻어 진행하였다(승인번호: 2017-07-028-001).

$\mathrm{A}$ 군 연쇄구균 신속항원검사는 상품화된 BioSign ${ }^{\circledR}$ Strep A Flip(lifeSign, Skillman, NJ, USA)를 이용하였다. 검사 키트 내에 포함되어 있는 멸균된 면봉으로 환자의 구개편도 를 포함한 인두부에서 검체를 채취한 즉시 진단검사의학과 미생물부로 보내어 $\mathrm{A}$ 군 연쇄구균 항체와 반응시킨 후 키트 내 양성 대조군과 같은 반응이 나타나는지 관찰하였다. 검체 를 항체와 반응시킨 후 10 분 내 반응이 나타나는 경우를 양 성으로 판정하였다.

대상 환자별로 나이, 성별, Centor score 증상 지표들의 유무 
$\left(38^{\circ} \mathrm{C}\right.$ 이상의 발열, 기침, 편도 종창, 편도 삼출물, 전경부 림 프절 종창 또는 압통), 콧물 및 코막힘 유무, 오한 및 전신 근 육통 유무, 인두 농양 형성 여부, 응급실 내원 당일 시행한 혈액검사에서의 C-반응단백(C-reactive protein, CRP) 수치 및 $\mathrm{A}$ 군 연쇄구균 신속항원검사 결과를 정리하였으며, 각 증 상 및 징후에 대해 언급되지 않은 경우는 결과분석에서 제외 하였다. 발열의 경우 응급실 내원 당시 측정한 체온을 기준으 로 하였으며, 전경부 림프절염 여부는 환자가 전경부 림프절 의 비대 및 압통을 호소하거나, 경부 전산화단층촬영에서 반 응성 림프절 비대가 확인된 경우를 유효한 것으로 하였다. 인 두 농양은 경부 전산화단층촬영에서 편도 및 편도 주위 공간 또는 하인두에 형성된 농양이 확인된 경우를 대상으로 하였 다. 대상 환자들 중 신속항원검사 양성그룹에서 3 명, 신속항 원검사 음성그룹에서 7명이 응급실 내원 전 항생제를 복용한 것으로 진술하였으나, 복용한 항생제가 환자의 증상 및 제균 정도에 미치는 영향이 명확하지 않고, 약물 복용력을 진술하 지 않은 환자들에서도 파악되지 않은 항생제 복용력이 있을 수 있어, 해당 환자들을 결과분석에서 제외하지는 않았다.

통계처리는 SPSS software version 19.0(IBM Corp., Armonk, NY, USA) 프로그램을 이용하였다. 각각의 증상 및 징후들과 $\mathrm{A}$ 군 연쇄구균 신속항원검사 결과 간의 연관성을 분석하기 위해 Pearson chi-squared test를 이용하였고, 기대 빈도가 5 미만인 경우는 Fisher's exact test를 이용하였다. Centor score 및 CRP와 같은 연속형 변수와 신속항원검사 결 과 간의 연관성 분석에는 정규성 검정(Kolmogorov-Smirnov) 에서 데이터가 비정규 분포함에 따라 Mann-Whitney test를 이용하였고, 중앙값(median)과 사분위수(interquantile range) 로 표시하였다. 신속항원검사 결과에 각 변수들이 관련된 정 도를 분석하기 위해 logistic regression test를 이용하였으며, 모든 통계분석에서 통계학적 유의성은 $p<0.05$ 인 경우를 기 준으로 하였다.

\section{결 과}

분석 대상인 379명의 급성 인두염 환자들 중 49 명에서 $\mathrm{A}$ 군 연쇄구균 신속항원검사 양성 반응이 확인되었다. 이들 중 남성이 26명(53.1\%), 여성이 23명(46.9\%)이었으며, 신속항원검 사 음성이 확인된 환자 330명 중 남성은 156명(47.3\%), 여성은 174 명(52.7\%)이었다. 신속항원검사 양성 그룹의 평균 연령은 $39.75( \pm 13.35)$, 음성 그룹의 평균 연령은 $34.65( \pm 11.80)$ 였으 며, 급성 인두염 환자들 중 30 대의 비율이 135 명(35.6\%)으로 가장 높았고, 신속항원검사 양성이 확인된 환자들 중에서도 30 대의 비율이 19 명(38.8\%)으로 가장 높았다. Fig. 1은 급성 인두염 환자들 및 신속항원검사 양성이 확인된 환자들의 연 령 그룹별 분포를 나타내고 있다.

임상 증상 및 징후는 전체 급성 인두염 환자 379 명 중 $38^{\circ} \mathrm{C}$ 이상의 발열이 198 명(52.2\%)에서 있었고, 인두의 발적만 확인 된 경우는 111명(29.2\%), 편도 비대는 268명(70.7\%), 편도의 삼 출물은 116 명(30.6\%)에서 확인되었다. 경부 림프절의 비대 또 는 압통은 82명(21.6\%), 기침은 203명(54.6\%), 콧물 또는 코막 힘은 110명(29.0\%), 전신 근육통 또는 오한은 248명(65.4\%), 인두 농양 형성은 11명(2.9\%)에서 있었다(Table 2). 신속항원 검사 양성이 확인된 49명(12.9\%)의 환자들에서 Centor score 는 각각 5 명에서 0 점, 17 명에서 1점, 18명에서 2점, 7명에서 3 점, 2 명에서 4점이었으며, 신속항원검사 음성이 확인된 330명 (87.0\%)의 환자들에서는 각각 13명에서 0점, 77 명에서 1점, 114명에서 2점, 95명에서 3점, 31명에서 4점이었다(Fig. 2).

$\mathrm{A}$ 군 연쇄구균 신속항원검사 양성 여부와 Centor score의 구성 지표들을 포함한 환자의 증상 및 징후와의 연관성을 분 석한 결과 신속항원검사 결과와 발열, 기침, 편도의 비대, 콧 물 또는 코막힘, 전신 근육통 또는 오한이 나타나는 환자 수 는 통계학적으로 유의한 연관성을 보이지 않았고 $(p>0.05)$, 편 도의 삼출물, 경부 림프절의 비대 또는 압통, 인두 농양 형성 을 나타내는 환자 수는 신속항원검사 양성 그룹에서 통계학

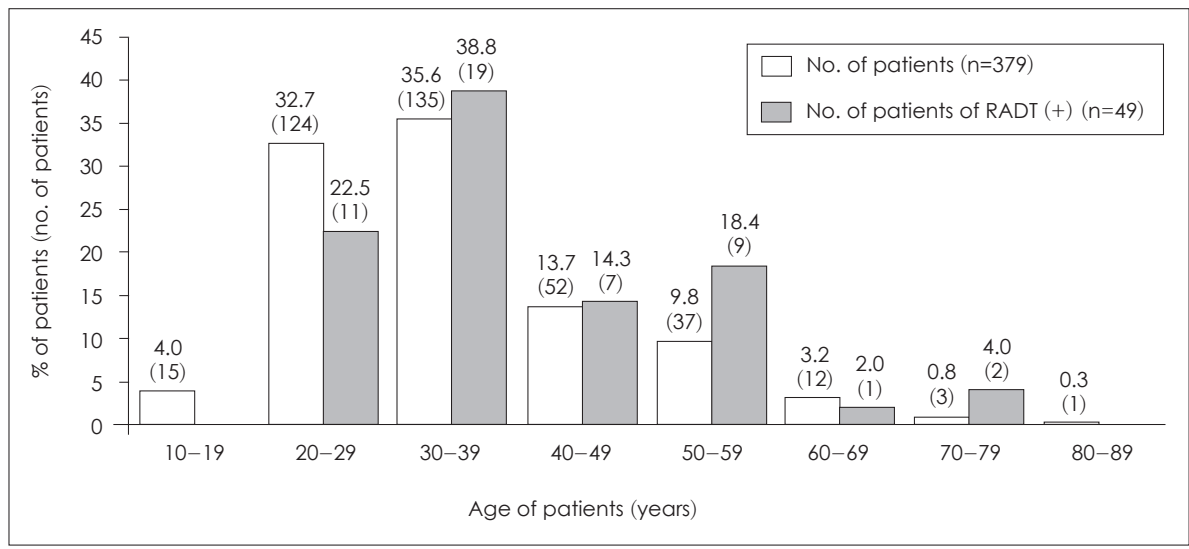

Fig. 1. Distribution of patients number of visiting emergency part. RADT: rapid antigen detection test. 
적으로 유의하게 더 많은 것으로 나타났다 $(p<0.05)$. Centor score 및 $\mathrm{CRP}$ 는 신속항원검사 양성 그룹에서 유의하게 더 높은 경향을 보였다 $(p<0.05)$ (Table 3).

신속항원검사 결과에 각각 변수들이 미치는 영향에 대한 단 변수 분석에서는 편도의 삼출물, 경부 림프절의 비대 또는 압 통, 인두 농양 형성이 있을수록, Centor score 및 CRP가 높을 수록, 나이가 많을수록 유의하게 신속항원검사 결과가 양성 일 확률이 높아졌다 $(p<0.05)$ (Table 4). 단변수 분석에서 유

Table 2. Symptoms and signs of patients diagnosed with acute pharyngitis

\begin{tabular}{lc}
\hline \multicolumn{1}{c}{ Parameters } & $\mathrm{n}=379, \mathrm{n}(\%)$ \\
\hline Fever $\left(>38.0^{\circ} \mathrm{C}\right)$ & $198(52.2)$ \\
Pharyngeal injection & $111(29.2)$ \\
Tonsillar hypertrophy & $268(70.7)$ \\
Tonsillar exudates & $116(30.6)$ \\
Tenderness or enlargement of cervical nodes & $82(21.6)$ \\
Cough & $203(54.6)$ \\
Runny nose or congestion & $110(29.0)$ \\
Myalgia or chilling & $248(65.4)$ \\
Abscess formation & $11(2.9)$ \\
\hline
\end{tabular}

의성이 확인된 6가지 변수들 사이의 상호 영향을 보정하여 각 변수들이 실제로 미치는 영향의 정도를 비교한 다변수 분석 에서는 신속항원검사가 양성으로 도출되는 데에 편도의 삼출 물, 경부 림프절의 비대 또는 압통, 나이의 세 가지 요인이 유의 하게 영향을 미치는 것으로 나타났고 $(p<0.05)$, 이들 중 편도 의 삼출물이 가장 높은 교차비로 관련이 있었고 $\{2.507[95 \%$ confidence interval(CI), 1.232-5.099]\}, 다음으로 경부 림프절 의 비대 또는 압통[2.435(95\% CI, 1.225-4.838)], 나이[1.043(95\% CI, 1.017-1.069)] 순으로 나타났다(Table 5).

\section{고 찰}

급성 인두염에서 $\mathrm{A}$ 군 연쇄구균 감염이 차지하는 비율은 $5 ~ 15 \%$ 범위에서 보고되고 있으며, 본 연구에서도 A군 연쇄 구균 신속항원검사 양성률이 $12.9 \%$ 로 나타났다. 우리나라에 서 2009년 7월부터 2011년 4월까지 전국적 규모의 급성 인후 염 감시사업을 실시한 결과, 약 $83 \%$ 정도는 바이러스가 주요 원인으로 국내 급성 인두염 발생도 전 세계적 경향과 같이 바 이러스 감염에 의한 빈도가 높음을 확인하였다. A군 사슬알

Fig. 2. Centor score and number of patient of RADT result. RADT: rapid antigen detection test.

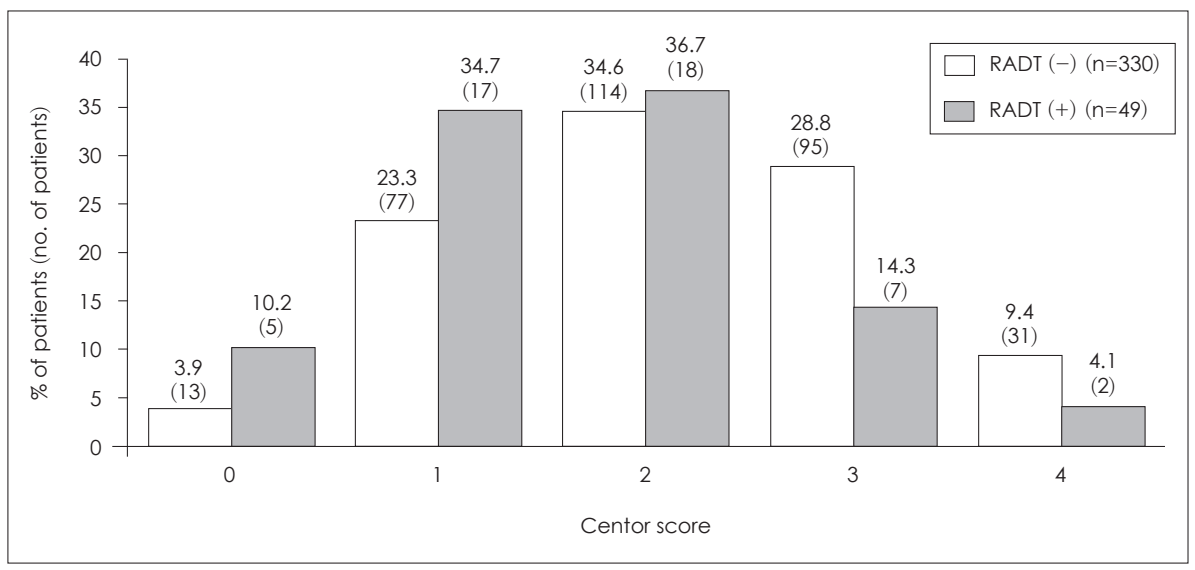

Table 3. Comparison of RADT positive and negative groups

\begin{tabular}{llcc}
\hline \multicolumn{1}{c}{ Parameters } & RADT $(+)(\mathrm{n}=49)$ & RADT $(-)(\mathrm{n}=330)$ & p value $^{\dagger}$ \\
\hline Fever $\left(>38.0^{\circ} \mathrm{C}\right), \mathrm{n}(\%)$ & $31(63.3)$ & $167(50.6)$ & 0.098 \\
Absence of cough, $\mathrm{n}(\%)$ & $28(57.1)$ & $148(44.8)$ & 0.107 \\
Tonsillar hypertrophy, $\mathrm{n}(\%)$ & $36(73.5)$ & $232(70.3)$ & 0.649 \\
Tonsillar exudates, $\mathrm{n}(\%)$ & $24(49.0)$ & $92(27.9)$ & $0.003^{*}$ \\
Lymph node Td/enlargement, $\mathrm{n}(\%)$ & $21(42.9)$ & $61(18.5)$ & $<0.001^{*}$ \\
Runny nose/congestion, $\mathrm{n}(\%)$ & $14(28.6)$ & $96(29.1)$ & 0.940 \\
Myalgia/chilling, $\mathrm{n}(\%)$ & $35(71.4)$ & $213(64.5)$ & 0.344 \\
Abscess formation, $\mathrm{n}(\%) \neq$ & $4(8.2)$ & $7(2.1)$ & $0.041^{*}$ \\
Centor score median (IQR)§ & $2(2-3)$ & $2(1-3)$ & $0.002^{*}$ \\
CRP median (IQR)\& & $3.72(1.01-10.47)$ & $1.36(0.40-3.93)$ & $0.001^{*}$ \\
\hline
\end{tabular}

*statistically significant $p$-value, ${ }^{\dagger} p$-value by chi-squared test, $\ddagger$ abscess formation: Fisher’s exact test, $\$$ Centor score median \& CRP median: Mann-Whitney test. RADT: rapid antigen detection test, Td: tenderness, IQR: interquantile range, CRP: C-reactive protein 
Table 4. Results of the univariate analysis

\begin{tabular}{|c|c|c|c|c|}
\hline \multirow{3}{*}{ Parameters } & \multirow{3}{*}{ OR } & \multicolumn{2}{|c|}{ Univariate analysis } & \multirow{3}{*}{$p$-value } \\
\hline & & \multicolumn{2}{|c|}{$95 \% \mathrm{Cl}$} & \\
\hline & & Lower & Upper & \\
\hline Age & 1.032 & 1.009 & 1.055 & $0.007^{*}$ \\
\hline Fever $\left(>38.0^{\circ} \mathrm{C}\right)$ & 1.681 & 0.905 & 3.124 & 0.100 \\
\hline Absence of cough & 1.640 & 0.895 & 3.005 & 0.110 \\
\hline Tonsillar exudate & 2.483 & 1.350 & 4.569 & $0.003^{*}$ \\
\hline Lymph node Td/enlargement & 3.307 & 1.761 & 6.212 & $<0.001^{*}$ \\
\hline Abscess formation & 4.102 & 1.155 & 14.568 & $0.029 *$ \\
\hline Centor score & 1.625 & 1.191 & 2.218 & $0.002^{*}$ \\
\hline CRP & 1.095 & 1.040 & 1.154 & $0.001^{*}$ \\
\hline
\end{tabular}

*statistically significant $p$-value. OR: odds ratio, Cl: confidence interval, Td: tenderness, CRP: C-reactive protein

Table 5. Results of the multivariate analysis

\begin{tabular}{|c|c|c|c|c|}
\hline \multirow{4}{*}{ Parameters } & \multirow{2}{*}{\multicolumn{4}{|c|}{ Multivariate analysis }} \\
\hline & & & & \\
\hline & \multirow{2}{*}{ OR } & \multicolumn{2}{|c|}{$95 \% \mathrm{Cl}$} & \multirow[t]{2}{*}{$p$-value } \\
\hline & & Lower & Upper & \\
\hline Age $\left(x_{1}\right)$ & 1.043 & 1.017 & 1.069 & $0.001^{*}$ \\
\hline Tonsillar exudates $\left(x_{2}\right)$ & 2.507 & 1.232 & 5.099 & $0.011^{*}$ \\
\hline Lymph node Td/enlargement $\left(x_{3}\right)$ & 2.435 & 1.225 & 4.838 & $0.011^{*}$ \\
\hline
\end{tabular}

*statistically significant $p$-value. Regression equation: $\log (p / 1-p)=-4.074+0.042 x_{1}+0.919 x_{2}+0.890 x_{3}$. OR: odds ratio, Cl: confidence interval

균 감염에 의한 급성 인후염의 빈도가 $7.9 \%$ 로 낮았고 바이러 스성 인후염의 비율이 높게 확인되었지만 실제 의료현장에서 는 환자의 $43.1 \%$ 에서 항생제 처방이 이루어져 불필요한 항생 제 처방이 다수 있었음을 시사한다. ${ }^{10)}$

급성 인두염은 주로 바이러스가 원인이 되며, 대부분 항생 제 투여 없이 호전되는 양성 경과를 보이나, $\mathrm{A}$ 군 연쇄구균이 원인이 될 경우 화농성 또는 비화농성 합병증을 일으킬 수 있어 이에 대한 정확한 진단과 치료가 요구되고 있다. 정확한 검사 결과 도출을 위해서는 정확한 검체의 채취가 중요한데, 검체 채취 과정에서 면봉이 혀나 볼 점막과 같은 구강 내 다 른 부위에 닿거나, 타액이 검체에 섞이는 경우, 검체 채취 후 검 사실로의 수송이 지연되는 경우 위음성이 발생할 수 있다.) 또 한 신속항원검사에서 음성으로 확인된 환자들 중 7명이 응급 실 내원 전에 외부 병원에서 처방받은 아목시실린 또는 세팔 로스포린계 항생제를 복용하고 있었으며, 환자의 진술 없이 는 정확한 약물 복용력의 파악이 어렵다는 점에서 다수의 환 자들에서 위음성이 발생했을 가능성이 있다. 신속항원검사 는 A군 연쇄구균의 항원 유무만을 확인할 수 있으며, 새로운 감염자와 보균자를 구분할 수 없어 신속항원검사 양성군에 다른 원인균에 의한 급성 인두염 환자가 포함되어 있을 가능 성 역시 배제할 수 없다.

$\mathrm{A}$ 군 연쇄구균 인두염 여부를 확인하는 표준 진단 방법은 인두도말배양검사이나, 본 연구에서는 연구 대상이 되는 환
자들에게 일괄적으로 인두배양검사를 시행하지 않아 신속항 원검사 결과의 타당도를 평가하지 못했다는 한계가 있다. 그 러나 현재 상용화된 신속항원검사들은 인두배양검사 결과와 비교하였을 때 기존에 시행되었던 여러 연구들에서 $90 \%$ 이 상의 민감도와 특이도가 확인된 유용한 검사로, ${ }^{11-13)}$ 인두배 양검사를 진단 및 치료에 이용하기 어려운 실제 임상 상황에 서 인두배양검사를 대체하여 사용할 수 있을 것으로 사료된 다. 본 연구에서 사용한 BioSign ${ }^{\circledR}$ Strep A 역시 자체 평가에 서 $96.2 \%$ 의 민감도와 $98.7 \%$ 의 특이도를 나타낸 바 있다. 국 내에는 A군 사슬알균 신속항원검사에 대한 급여 인정 기준이 2009년 11월에 제시되었으며, 만 3세부터 만 15세까지 소아에 서 $38^{\circ} \mathrm{C}$ 이상의 열이 있으면서 다음 증상 (1) 인후통, (2) 두 통, (3) 인두발적 및 삼출물, (4) 경부 림프절 비대 또는 동통, (5) 성홍열 모양의 발적) 중 3가지 이상이 있는 경우이다. ${ }^{14)}$ 신 속항원검사 급여 기준을 성인에까지 확대하여 전 연령대에 걸 쳐 검사의 시행률을 높이는 것이, $\mathrm{A}$ 군 연쇄구균 인두염의 조 기 진단과 적절한 항생제 치료에 도움이 될 수 있을 것이다.

$\mathrm{C}$-반응단백(CRP)은 그 수치 상승이 A군 연쇄구균 감염과 유의한 연관성이 없는 것으로 보고되어 왔으며, 이에 따라 $\mathrm{A}$ 군 연쇄구균 인두염의 진단에 일상적으로 사용하지 않도록 권고되어 왔다. ${ }^{6,15}$ 본 연구에서 확인된 $\mathrm{CRP}$ 상승과 신속항 원검사 양성 결과와의 유의한 연관성은 $\mathrm{A}$ 군 연쇄구균 감염 과의 직접적인 연관성보다는 $\mathrm{CRP}$ 의 세균 감염과의 연관성 
및 질병의 심각성, 농양 형성 등 합병증과의 연관성에 의한 결 과일 가능성이 더 높다. CRP는 급성 인두염의 경과 및 치료 결과의 감시, 편도 주위 농양과 같은 합병증이 의심될 때에 그 유용성을 인정받아 왔으며, 앞으로도 A군 연쇄구균 인두 염뿐만이 아닌 다른 원인에 의한 인두염의 진단 및 치료 과정 에서도 보조적인 역할로 기능할 수 있을 것이다.

본 연구에서는 인두 농양 형성을 나타내는 환자 수가 신속 항원검사 양성 그룹에서 유의하게 더 많은 것으로 나타나, 이 론적으로 농양 형성과 같은 화농성 합병증의 예방에 $\mathrm{A}$ 군 연 쇄구균 감염의 신속한 치료가 도움이 될 수 있으나, 많은 경우 에서 농양이 형성된 이후 처음 내원하여 $\mathrm{A}$ 군 연쇄구균 감염 이 진단되므로 ${ }^{5)}$ 실질적으로 농양 형성의 위험성을 줄이기는 어려울 것으로 보인다.

현재 개발되어 있는 가이드라인들에서는 $\mathrm{A}$ 군 연쇄구균 감 염에 의한 인두염 여부를 확인하기 위한 임상 지표인 Centor score에 따른 신속항원검사 시행 및 경험적 항생제 사용 지 침을 제시하고 있으나, 그 세부 내용들은 가이드라인마다 차 이가 있다. Centor score에서 0 또는 1점에 해당하는 경우 추 가적인 균 검사나 항생제 사용이 필요하지 않으며, 4점에 해당 하는 경우 경험적 항생제를 사용하는 것이 권고된다는 사항 에는 대부분 일치된 의견을 보인다. ${ }^{3}$ 그러나 2 또는 3 점에 해 당하는 경우 지속적인 논쟁이 이루어지고 있으며, 가이드라 인마다 권고하는 방향이 다르다. 미국이나 일부 유럽 국가에 서는 류마티스 열의 발생률이 낮아, 인후배양검사나 신속항 원검사에서 양성 결과가 도출되는 경우 항생제 사용을 고려 할 것을 권고한다. 신속항원검사에서 음성이 확인되었을 때 성인의 경우에는 인후배양검사를 추가로 권고하지 않으나, 소아의 경우에는 시행할 것을 권고하며, 일부 가이드라인에서 는 성인의 경우에도 추가로 시행할 것을 권고한다. 이에 반해 유럽의 여러 국가들에서는 급성 인두염의 양성 경과에 주목 하여 균 검사를 일상적으로 시행하지 않을 것 및 매우 선별된 항생제 사용을 권고한다. 류마티스 열과 같은 합병증의 발생 빈도가 여전히 높으며, 공공의료 서비스가 낙후된 브라질 및 개발도상국들에서는 배양검사 및 항원검사 시행이 어려우므 로 Centor score 2 이상에서 항생제 사용이 권고되기도 한다. ${ }^{1)}$ 우리나라는 2016년에 질병관리본부에서 발표한 소아 급성 상 기도 감염 시 항생제 사용 지침에 따르면 Centor score 3 4점 이상인 경우 $\mathrm{A}$ 군 사슬알균 진단검사를 시행할 수 있으며 (Grade B, Level III), 인두 검체에서 신속항원검사 혹은 배양 검사를 시행하여 $\mathrm{A}$ 군 사슬알균이 검출된 경우 $\mathrm{A}$ 군 사슬알 균 인두편도염으로 진단하고 항생제 치료를 할 수 있다. ${ }^{14)}$

본 연구에서는 Centor score가 높을수록 신속항원검사 결 과가 양성으로 도출될 확률이 유의하게 높게 나타나, 기존에
이루어졌던 급성 인두염 환자의 임상 증상과 신속항원검사를 포함한 미생물 검사 결과와의 연관성을 확인한 연구들과 일 치하는 결과를 보였다. 특히 편도의 삼출물, 경부 림프절의 비 대 또는 압통이 발열 또는 기침과 같은 Centor score의 다른 지표보다 신속항원검사 양성 결과와의 높은 연관성을 보여, Centor score에서 같은 점수의 급성 인두염 환자라도 해당 증상들을 보일 경우 $\mathrm{A}$ 군 사슬알균 감염 가능성이 더 높다고 할 수 있을 것이다. 이러한 결과는 우리나라에서 성인을 상대 로 한 급성 인두편도염 시 항생제 치료 가이드라인이 나와 있 지 않은 현재 실정에서, Centor score 2점 또는 3점의 임상 증 상을 보이는 환자의 진단 및 치료를 계획할 때 판단의 근거로 서 도움이 될 수 있을 것이다. 인두배양검사의 결과 확인에 18 48시간이 소요되고, 검사 시행을 위해서는 미생물검사 실 및 배양 시설이 필요하여 실제 임상에서의 활용이 어려운 실정에서, 신속항원검사 결과 및 Centor score를 통한 환자 의 증상 평가를 종합적으로 활용하는 것은 무분별한 경험적 항생제 사용을 억제하여 내성균의 출현 및 과민 반응을 포 함한 약제 부작용, 그리고 보건비용 증가의 문제를 해결하는 방법으로 기능하게 될 것이다. 또한 조기에 항생제를 투여할 것인지의 결정에 도움을 주어 임상 증상의 빠른 호전과 $\mathrm{A}$ 군 연쇄구균 감염의 합병증 예방에 기여할 것으로 판단된다.

\section{REFERENCES}

1) Chiappini E, Regoli M, Bonsignori F, Sollai S, Parretti A, Galli L, et al. Analysis of different recommendations from international guidelines for the management of acute pharyngitis in adults and children. Clin Ther 2011;33(1):48-58.

2) Centor RM, Witherspoon JM, Dalton HP, Brody CE, Link K. The diagnosis of strep throat in adults in the emergency room. Med Decis Making 1981;1(3):239-46.

3) Anjos LM, Marcondes MB, Lima MF, Mondelli AL, Okoshi MP. Streptococcal acute pharyngitis. Rev Soc Bras Med Trop 2014;47(4): 409-13.

4) Wessels MR. Clinical practice. Streptococcal pharyngitis. N Engl J Med 2011;364(7):648-55.

5) Cooper RJ, Hoffman JR, Bartlett JG, Besser RE, Gonzales R, Hickner JM, et al. Principles of appropriate antibiotic use for acute pharyngitis in adults: background. Ann Intern Med 2001;134(6): 509-17.

6) Windfuhr JP, Toepfner N, Steffen G, Waldfahrer F, Berner R. Clinical practice guideline: tonsillitis I. Diagnostics and nonsurgical management. Eur Arch Otorhinolaryngol 2016;273(4):973-87.

7) Aalbers J, O’Brien KK, Chan WS, Falk GA, Teljeur C, Dimitrov BD, et al. Predicting streptococcal pharyngitis in adults in primary care: a systematic review of the diagnostic accuracy of symptoms and signs and validation of the Centor score. BMC Med 2011;9:67.

8) Llor C, Hernández Anadón S, Gómez Bertomeu FF, Santamaria Puig JM, Calviño Domínguez O, Fernández Pagés Y. [Validation of a rapid antigenic test in the diagnosis of pharyngitis caused by group a beta-haemolytic Streptococcus]. Aten Primaria 2008;40(10):489-94.

9) Shulman ST, Bisno AL, Clegg HW, Gerber MA, Kaplan EL, Lee G, et al. Clinical practice guideline for the diagnosis and management of group A streptococcal pharyngitis: 2012 update by the Infectious 
Diseases Society of America. Clin Infect Dis 2012;55(10):e86-102.

10) Bae SM. Respiratory bacteria and viruses in the etiology of acute pharyngitis in Korea. KCDC PHWR 2012;5(4):58-63.

11) Kim IU, Yang MY, Jung HR, Kang EK, Huh HJ. Clinical manifestations of group A streptococcal pharyngitis and comparison of usefulness of two rapid streptococcal antigen tests. Lab Med Online 2016;6(2): 88-92.

12) Stefaniuk E, Bosacka K, Wanke-Rytt M, Hryniewicz W. The use of rapid test QuikRead go ${ }^{\circledR}$ Strep A in bacterial pharyngotonsillitis diagnosing and therapeutic decisions. Eur J Clin Microbiol Infect Dis 2017 Apr 21 [Epub ahead of print]. http://doi.org/10.1007/s10096-0172986-8.
13) Kose E, Sirin Kose S, Akca D, Yildiz K, Elmas C, Baris M, et al. The effect of rapid antigen detection test on antibiotic prescription decision of clinicians and reducing antibiotic costs in children with acute pharyngitis. J Trop Pediatr 2016;62(4):308-15.

14) Choi EH, Lee HJ, Park SE, Cho DS, Lee JA, Yoon KU, et al. Guidelines for the antibiotic use in children with acute upper respiratory tract infections. Cheongju, Korea: KCDC;2016. p.19-30.

15) Calviño O, Llor C, Gómez F, González E, Sarvisé C, Hernández S. Association between $\mathrm{C}$-reactive protein rapid test and group A streptococcus infection in acute pharyngitis. J Am Board Fam Med 2014;27(3):424-6 